\title{
Methods for the routine characterisation of isolates of Haemophilus
}

\author{
PM ZADIK \\ From the Public Health Laboratory and Department of Microbiology, Royal Berkshire Hospital, London \\ Road, Reading, Berkshire, RG1 5AN
}

SUMMARY Methods and their evaluation are described for the routine characterisation of Haemophilus spp isolates using a test for dependence on $\mathrm{V}$ factor and a test for the conversion of delta-amino-laevulinic acid (ALA) to porphyrin in which the ALA is incorporated into a solid medium. A method is also described whereby the difference in the size of the inhibition zones around discs of ampicillin and of amoxycillin/clavulanate can be used to detect the production of beta-lactamase.

As a result of problems with the determination of the requirement for haemin ( $\mathrm{X}$ factor) by strains of Haemophilus spp, Kilian ${ }^{1}$ introduced a method based on the ability of strains independent of haemin to convert delta-amino-laevulinic acid (ALA) into protoporphyrin. This paper describes the use and evaluation of this reaction, when the ALA is incorporated into a solid medium, in the routine characterisation of isolates.

The production of beta-lactamase by haemophili is at present mainily detected by two methods-the hydrolysis of a chromogenic cephalosporin ${ }^{2}$ or the detection of $\mathrm{pH}$ change on the hydrolysis of penicillin as in the paper strip test. ${ }^{3}$ The method described here uses the observed differences in the diameters of the zones of inhibition of growth around ampicillin discs and amoxycillin clavulanate discs, where the clavulanate protects the amoxycillin from hydrolysis, to distinguish between strains that produce beta-lactamase and those that do not.

\section{Material and methods}

BACTERIAL STRAINS

Thirty-two strains of Haemophilus spp were kindly provided by the National Collection of Type Cultures. There were as follows: $\boldsymbol{H}$ influenzae NCTC $8465,8466,7279,8467,8433,8143,8469,8502$, $8134,8135,4560,4842,8468,8470,10479,8455$, 8472; H haemolyticus NCTC 10659; $H$ parainfluenzae NCTC 7857, 10558, 10665, 8479, 10794, $10670,10671,10672 ; H$ paraphrophilus NCTC

Accepted for publication 3 February 1982
10556, 10557; $H$ aphrophilus NCTC 5886, 5906, 5907,5908 . In addition, 219 clinical isolates were obtained from our laboratory. All strains were stored until required at $-70^{\circ} \mathrm{C}$ as a turbid suspension in peptone water.

\section{METHOD FOR IDENTIFICATION}

The media for the determination of species are poured into two-compartment Petri dishes with on? compartment containing $9 \mathrm{ml}$ of Blood Agar Base No 2 (Oxoid) with $0.1 \%$ dextrose and with $2 \%$ $(\mathrm{vol} / \mathrm{vol})$ of haemin solution $(0 \cdot 1 \%(\mathrm{wt} / \mathrm{vol})$ haematin hydrochloride in $0.1 M \mathrm{Na}_{2} \mathrm{HPO}_{4}$ solution, autoclaved at $121^{\circ} \mathrm{C}$ for $15 \mathrm{~min}$ ) added just before pouring. The other compartment contains $9 \mathrm{ml}$ of $10 \%$ heated horse blood (chocolate) agar in Blood Agar Base No 2 with $2 \%$ (vol/vol) of ALA solution (3.6\% (wt/vol) ALA (BDH) with $1 \%$ (wt/vol) $\mathrm{MgSO}_{4} .7 \mathrm{H}_{2} \mathrm{O}$ in distilled water sterilised by membrane filtration) which is added just prior to pouring. One plate is used for every batch of isolates tested. One colony of the organism is emulsified in $3 \mathrm{ml}$ of peptone water and loopfuls are applied with $4 \mathrm{~mm}$ diameter sterile loops to single marked spots on both halves of the Petri dish. Up to 10 strains may be accommodated on one plate. A strain of $H$ parainfluenzae is included, as a positive control for the ALA medium, with each batch. The plate is incubated for $18 \mathrm{~h}$ at $37^{\circ} \mathrm{C}$ in an atmosphere containing $10 \% \mathrm{CO}_{2}$ and is then examined for the presence of growth on the medium which contains haemin and for red fluorescence of the bacterial growth on the medium containing ALA when examined under a Wood's lamp. The species of the isolate can be determined by reference to Table 1 . 
Table 1 Interpretation of results from the media for identification

\begin{tabular}{lll}
\hline & $\begin{array}{l}\text { Porphyrins } \\
\text { produced }\end{array}$ & $\begin{array}{l}\text { Porphyrins not } \\
\text { produced }\end{array}$ \\
\hline $\begin{array}{l}\text { Growth on } \\
\text { haemin-containing } \\
\text { medium }\end{array}$ & - & H aphrophilus \\
$\begin{array}{l}\text { No growth on } \\
\text { haemin-containing } \\
\text { medium }\end{array}$ & $\begin{array}{l}\text { H parainfuenzae } \\
\text { Haraphrophilus }\end{array}$ & $\begin{array}{l}\text { H influenzae } \\
\text { H haemolyticum }\end{array}$ \\
\hline
\end{tabular}

\section{EVALUATION OF THE MEDIA USED FOR}

IDENTIFICATION

Unautoclaved yeast extract was prepared by heating $50 \mathrm{~g}$ of fresh baker's yeast with $100 \mathrm{ml}$ of $0.2 \mathrm{M}$ $\mathrm{KH}_{2} \mathrm{PO}_{4}$ solution at $80^{\circ} \mathrm{C}$ for $20 \mathrm{~min}$. After centrifugation the supernatant was prefiltered through filter paper, sterilised by passing through a $0.2 \mu \mathrm{m}$ cellulose acetate membrane and then stored, until required, at $-20^{\circ} \mathrm{C}$.

Petri dishes were prepared containing $20 \mathrm{ml}$ of the ALA medium decribed above. Three sets of plates were also prepared containing $20 \mathrm{ml}$ of Blood Agar Base No 2 with $0.1 \%$ glucose and either $0.4 \mathrm{ml}$ of unautoclaved yeast extract alone, $0.4 \mathrm{ml}$ of haemin solution alone or both together, added just before pouring.

Strains were characterised in batches of 20 . They were applied by means of a Multipoint Inoculator A400 (Denley-Tech Limited) as suspensions in sterile saline. The size of each inoculum was about 2 $\times 10^{5}$ organisms. One each of the above four plates was inoculated. The plates were then incubated for $18 \mathrm{~h}$ at $37^{\circ} \mathrm{C}$ in an atmosphere containing $10 \% \mathrm{CO}_{2}$. Requirement for $\mathrm{X}$ factor or yeast extract ( $\mathrm{V}$ factor) was detected as a lack of, or a marked reduction in, growth on the plates containing yeast extract or haemin respectively as compared with the control plate containing both factors. The production of porphyrin from ALA was detected as described above.

DETECTION OF BETA-LACTAMASE PRODUCTION The sensitivity tests are carried out on $10 \%$ heated horse blood agar with Blood Agar Base No 2. The inoculum should give a semiconfluent growth and the test is carried out with the test strain and a fully sensitive control strain on either side of discs containing $25 \mu \mathrm{g}$ of ampicillin and $20 \mu \mathrm{g}$ amoxycillin/10 $\mu \mathrm{g}$ clavulanate (Augmentin (R)). The zones of inhibition are measured after $18 \mathrm{~h}$ incubation at $37^{\circ} \mathrm{C}$ in an atmosphere containing $10 \% \mathrm{CO}_{2}$.

\section{EVALUATION OF THE METHOD FOR DETECTION OF BETA-LACTAMASE}

This was carried out using the method described above on three groups of organisms, all isolated in this laboratory.

(i) The first group consisted of 17 strains of $H$ influenzae, negative for the production of betalactamase by the method of Slack et $a l^{3}$ and for which the minimum inhibitory concentrations of ampicillin were equal to or less than $0.5 \mu \mathrm{g} / \mathrm{ml}$ when tested on heated blood agar.

(ii) The second group consisted of 15 strains of $H$ influenzae and two strains of $H$ parainfuenzae all of which were found to produce beta-lactamase by the method of Slack et al. $^{3}$

(iii) The third group consisted of five strains of $H$ influenzae, negative for the production of betalactamase and for which the minimal inhibitory concentrations of ampicillin were greater than $2 \mu \mathrm{g} / \mathrm{ml}$ when tested on heated blood agar. Also for these strains the minimum inhibitory concentrations of cefuroxime were raised at greater than $2 \mu \mathrm{g} / \mathrm{ml}$.

\section{Results}

MEDIA FOR IDENTIFICATION

The results for the NCTC strains, when tested with the media for identification are shown in Table 2 . It can be seen that, except for the four strains of $H$ aphrophilus, all strains independent of haemin gave a positive fluorescence on the ALA medium. Of the 219 clinical isolates none were independent of $\mathrm{V}$ factor and 24 were independent of haemin. All of these 24 strains gave a positive fluorescence on the ALA medium.

DETECTION OF BETA-LACTAMASE

The diameters of the zones of inhibition are given in

Table 2 Results on testing the NCTC strains

\begin{tabular}{|c|c|c|c|c|}
\hline & \multirow[b]{2}{*}{ No of strains } & \multicolumn{3}{|l|}{ No positive for: } \\
\hline & & $A L A$ to porphyrin & $X$ requirement & $V$ requirement \\
\hline $\begin{array}{l}H \text { infuenzae } \\
H \text { haemolyticus } \\
H \text { parainfuenzae } \\
H \text { paraphrophilus } \\
H \text { aphrophilus }\end{array}$ & $\begin{array}{r}17 \\
1 \\
8 \\
2 \\
4\end{array}$ & $\begin{array}{l}0 \\
0 \\
8 \\
2 \\
0\end{array}$ & $\begin{array}{r}17 \\
1 \\
0 \\
0 \\
0\end{array}$ & $\begin{array}{r}17 \\
1 \\
8 \\
2 \\
0\end{array}$ \\
\hline
\end{tabular}


Table 3 Inhibition zone diameters $(\mathrm{mm})$

\begin{tabular}{|c|c|c|c|c|c|c|}
\hline & \multicolumn{3}{|c|}{$\begin{array}{l}\text { Zone diameter around } \\
\text { ampicillin disc }\end{array}$} & \multicolumn{3}{|c|}{$\begin{array}{l}\text { Zone diameter around } \\
\text { amoxycillin/clavulanate disc }\end{array}$} \\
\hline & Mean & Range & $S D$ & Mean & Range & $S D$ \\
\hline $\begin{array}{l}\text { Sensitive strains } \\
(17 \times H \text { infuenzae })\end{array}$ & 29.41 & $27-36$ & $2 \cdot 37$ & $26 \cdot 71$ & $24-34$ & $2 \cdot 28$ \\
\hline $\begin{array}{l}\text { Beta-lactamase produci } \\
\text { strains } \\
(15 \times H \text { influenzae } \\
2 \times H \text { parainfluenzae })\end{array}$ & 16.65 & $14-20$ & $1 \cdot 73$ & $25 \cdot 24$ & $24-27$ & 0.97 \\
\hline $\begin{array}{l}\text { Other strains* } \\
(5 \times H \text { influenzae })\end{array}$ & $24 \cdot 80$ & $23-29$ & $2 \cdot 50$ & 23.00 & $17-28$ & 4.00 \\
\hline
\end{tabular}

${ }^{*}$ For these strains the minimum inhibitory concentrations of both ampicillin and cefuroxime were $\geqslant 2 \mu \mathrm{g} / \mathrm{ml}$ but they did not produce beta-lactamase.

Table 3. It can be seen that the zone sizes for those organisms which produced the beta-lactamase were reduced around the ampicillin discs when compared with the zones around the amoxycillin/clavulanate discs. The smallest difference between the zone diameters was $5 \mathrm{~mm}$ in the case of two of the strains. For both groups of organisms which did not produce beta-lactamase the zone sizes were found either to be slightly greater around the ampicillin disc or to be equal around both of the discs.

\section{Discussion}

This study suggests that a test with a solid medium containing ALA is a suitable replacement for a test for dependence on haemin. The results for both types of test were in agreement for all strains except for the type strains of $H$ aphrophilus. The detection of porphyrin production from ALA worked best with heated blood agar, rather than blood agar, and this was also the medium giving the most abundant growth. Haemin is freely available in this medium suggesting that, for $H$ parainfluenzae and $H$ paraphrophilus, either that haemin in the medium cannot be used or that the enzymes in the conversion of ALA to porphyrin may be constitutive. Haemophilus aphrophilus, giving a negative result in this test but a positive result in Kilian's, ${ }^{4}$ may be able to use haemin contained in the medium. When this test is used together with a test for dependence on $V$ factor, as described in the method, the vast majority of isolates can be divided into two categories. The first category comprises $H$ parainfluenzae and $H$ paraphrophilus and the second $H$ influenzae and $H$ haemolyticus. If further characterisation is required a test for haemolysis will give positive results for all isolates of $H$ haemolyticus and many isolates of $H$ parainfluenzae.

The test for the detection of beta-lactamase can be carried out as part of a routine sensitivity test although the medium used here, heated blood agar, is not suitable for the determination of sensitivities to trimethoprim and sulphonamides. The control organism should be fully sensitive in order to monitor the ampicillin and amoxycillin contents of the discs. In addition, a strain which produces betalactamase should be tested occasionally to monitor the clavulanate content. The inoculum size is very important when testing the susceptibilities of haemophili to beta-lactam antibiotics and this tese will probably be reliable only with a semiconfluerf inoculum. A positive result for the presence of beta-lactamase is obtained when the diameter of the zone of inhibition is greater around the amoxycillin/clavulanate disc than around the ampicillin disc and in this evaluation the difference in zone diameters was always equal to or greater than $5 \mathrm{~mm}$. For the control strain, and for any strain negative for beta-lactamase, the zone around the amoxycillin/clavulanate disc should be equal to or slightly less than the zone around the ampicillin disc.

I am indebted to Dr JV Dadswell for his criticism of the manuscript, to Dr LR Hill for the provision of type strains and to Mrs S Watson for typing the manuscript.

\section{References}

' Kilian M. A rapid method for the differentiation of Haemophilus species. The porphyrin test. Acta Pathol Microbiol Scand [B] 1974;82:835-42.

${ }^{2}$ O'Callaghan $\mathrm{CH}$, Morris A, Kirby SM, Shingler AH. Novel method for the detection of beta-lactamase by using a chromogenic cephalosporin substrate. Antimicrob Agents Chemother 1972;1:283-8.

${ }^{3}$ Slack MPE, Wheldon DB, Turk DC. A rapid test for beta- 
lactamase production by Haemophilus influenzae. Lancet 1977;ii:906.

${ }^{4}$ Kilian M. A taxonomic study of the genus Haemophilus, with the proposal of a new species. J Gen Microbiol 1976;93:9-62.
Requests for reprints to: Dr PM Zadik, Public Health Laboratory and Department of Microbiology, Royal Berkshire'Hospital, London Road, Reading, Berks RG1 5AN, England.

\section{The August 1982 issue}

\section{THE AUGUST 1982 ISSUE CONTAINS THE FOLLOWING PAPERS}

Oxygen transport in chronic hypoxic lung disease DC FLENLEY

Urine cyclic nucleotide concentrations in cancer and other conditions; cyclic GMP: a potential marker for cancer treatment GA TURNER. RD ELLIS. D GUTHRIE, AL LATNER, JM MONAGHAN, WM ROSS. AW SKILLEN, RG WILSON

Measurement of the fasting urinary hydroxyproline: creatinine ratio in normal adults and its variation with age and sex A HODGKINSON. T THOMPSON

Hyperplastic parathyroiditis - a new autoimmune disease? BF BOYCE. VR DOHERTY, G MORTIMER

Lysozyme in chronic liver disease: a biochemical and histological study IH MANIFOLD. FM BISHOP. P CLOKE. DR TRIGER. JCE UNDER WOOD

Distribution of plasma cells in normal rectal mucosa RCF LEONARD, ICM MACLENNAN

Angiodysplasias of the colon DJ POUNDER. R ROWLAND. AS PIETERSE, R FREEMAN, R HUNTER

Pathology of colorectal adenomas: a colonoscopic survey F KONISHI. BC MORSON

Fibroma of tendon sheath PS SMITH. AS PIETERSE. J MCCLURE

Recurring digital fibroma GMORTIMER. AAM GIBSON

Segmental lymph-node infarction after fine-needle aspiration JD DAVIES. AJ WEBB

A new manifestation of thrombocytopenia: myocardial haemorrhage with symptomatic arrhythmia PJ WYLD. S BECK. DN SLATER

Cytogenetic study in acute myeloid leukaemia using peripheral blood samples sent by post YSLI. FGJ HAYHOE
C-reactive protein concentration as a guide to antibiotic therapy in acute leukaemia KPSCHOFIELD. F VOULGARI, DI GOZZARD. MJ LEYLAND, NJ BEECHING, J STUART

Morphological and functional disturbances of platelets induced by cryopreservation H BAYTHOON. EGD TUDDENHAM, RA HUTTON

Biotyping of Enterobacter cloacae DC OLD

Value of the minimum bactericidal concentration of antibiotics in the management of a case of recurrent Streptococcus bovis septicaemia LENA ROBINSON, K FONSECA

A microcomputer system for clinical bacteriology: experience of 12 months trial RJ COURCOL. M ROUSSEL-DELVALLEZ, GR MARTIN

Frequency of Candida albicans serotypes in patients with denture-induced stomatitis and in normal denture wearers MV MARTIN, DJ LAMB

Enzyme-linked immunosorbent assay (ELISA) using antibody class capture for the detection of antitoxoplasma IgM RA PAYNE, M ISAAC, JANET M FRANCIS

\section{Technical methods}

Staining properties of human intestinal mucosal mast cells after glutaraldehyde fixation S STROBEL. M HASAN. ANNE FERGUSON

Manual screening for immune antitetanus antibodies by means of latex coated with tetanus toxoid JR BOOTH. PA NUTTALL

\section{Letters to the editor}

Notices

Some new titles

Book reviews

Copies are still available and may be obtained from the PUBL.ISHING MANAGER, BRITISH MEDICAL ASSOCIATION, TAVISTOCK SQUARE, LONDON WClH 9JR, price $£ 5.00$, including postage 